\title{
REACTION OF THE GOBLET CELLS TO THE CHOLINERGIC STIMULATION
}

\author{
V. KONRÁDOVÁ ${ }^{1}$, J. UHLIK ${ }^{1}$, L.VAJNER ${ }^{1}$, J. ZOCOVÁ ${ }^{2}$ \\ ${ }^{1}$ Institute of Histology and Embryology, $2^{\text {nd }}$ Medical Faculty, Charles University, Prague \\ ${ }^{2}$ Department of Applied Mathematics and Computer Science, Faculty of Science, Charles University, Prague
}

Received August 8, 1996

Accepted September 24, 1996

\begin{abstract}
Konrádová V., J. Uhlík, L. Vajner, J. Zocová,: Reaction of the Goblet Cells to the Cholinergic Stimulation. Acta vet. Brno 1996, 65: 175-180.

The reaction of goblet cells in the rabbit tracheal epithelium caused by the intravenous administration of $0.1 \mathrm{mg}$ and $0.5 \mathrm{mg}$ of acetylcholine, respectively, was studied. Due to the cholinergic stimulation the goblet cells were overstimulated, the mechanism of their secretion was accelerated and after rapid evacuation of their secretion the secretory elements mostly degenerated. Due to the administration of both doses of acetylcholine more than $90 \%$ of goblet cells were stimulated to discharge their mucus. After administration of $0.1 \mathrm{mg}$ of acetylcholine the reaction was more prolongated, but the peak values of the degenerated goblet cells did not differ significantly after administration of both doses of acetylcholine. Twenty min after administration of $0.5 \mathrm{mg}$ of acetylcholine the signs of massive differentiation of new secretory elements were encountered.
\end{abstract}

Tracheal goblet cells, ultrastructure, acetylcholine, rabbit

The airways' epithelium with its vital self-cleaning ability plays an important role in the pathogenesis of severe respiratory diseases known in human and veterinary pathology. At first a group of inborn defects of the ciliary apparatus was studied in detail. The "immotile cilia syndrome", described in humans by A f ze li u s (1976), was later discovered also in different animal species (Bry an 1983; Edwards et al. 1989; Roperto et al. 1993; Wilsman et al. 1987, U hlík et al. 1995). Recently importance of the secretory activity of the goblet cells was recognized and the complicated problem of mucus secretion control in the respiratory passages was summarized in detailed study by Ramnarine and Rogers (1994). In agreement with other authors (T o k u y a m a et al. 1990; Fung et al. 1992) they suggested that the cholinergic stimulation significantly contributed to this process. S pe ci a n and Ne u tra (1980) and later also Phillips and Wils on (1993) demonstrated rapid evacuation of the goblet cells and the change in the mechanism of their secretion due to the acetylcholine administration to rats in vivo, or to the slides and explants of the rabbit and rat intestine mucous membrane in vitro. After addition of this drug to the incubation medium of the colonic cancer cell lines, transient but significant increase in mucus secretion was also demonstrated (Roumagnac and Laboisse 1987). In these studies the goblet cells secretion was not quantified. Only T o k u y a m a and his fellow-workers used a semiquantitative morphometric technique at the level of the light microscopy to evaluate the mucus discharge due to cholinergic stimulation in the guinea pig airways (To k u y a ma et al. 1990). We therefore decided to study quantitatively the effect of administration of two different doses of acetylcholine on the secretory cycle and mechanism of the goblet cells' secretion.

Materials and Methods

In our experiments, 15 healthy rabbits (body mass $1,500-3,000 \mathrm{~g}$ ) were used. Three rabbits served as untreated controls. The remaining ones were divided in two groups, each consisting of 6 animals, and received i.v. $0.1 \mathrm{mg}$ or $0.5 \mathrm{mg}$ of acetylcholine (Ciba, Niederwangen, Belgium), respectively. The material was always collected from 3 rabbits $5 \mathrm{~min}$ and $20 \mathrm{~min}$ after i.v. administration of $0.1 \mathrm{mg}$ and $0.5 \mathrm{mg}$ of the drug. The tiny portions of the tracheal mucous membrane were fixed for $90 \mathrm{~min}$ in $5 \%$ glutaraldehyde (Merck, Hohenbrunn bei München, Germany) in 
$0.1 \mathrm{M}$ cacodylate buffer ( $\mathrm{pH} 7.2)$ and then postfixed for $60 \mathrm{~min}$ in $2 \% \mathrm{OsO}_{4}(\mathrm{JMC}$, London, United Kingdom) in $0.1 \mathrm{M}$ cacodylate buffer ( $\mathrm{pH} 7.4$ ), dehydrated in graded series of alcohol and embedded in a Durcupan-Epon mixture (Fluka, Buchs, Switzerland). Ultrathin sections were prepared on Ultrotome Nova (LKB, Bromma, Sweden), contrasted with uranyl acetate and lead citrate and examined in JEM 100 C electron microscope (Jeol, Tokyo, Japan).

Using our method, the functional state of goblet cells was evaluated quantitatively (Konrádová and Srajer 1987). The numbers of evaluated goblet cells in controls and after acetylcholine administration are given in Table 1. Relative values of the 3 categories of goblet cells were evaluated by the chi-square test of homogeneity in frequency tables. To specify categories causing deflections from the hypothesis of homogeneity, adjusted standardized deviations were used.

Table 1

Quantitative evaluation of the goblet cells (GC) in the tracheal epithelium of rabbits after administration of acetylcholine (absolute values)

\begin{tabular}{|c|c|c|c|c|c|c|c|c|c|c|c|c|c|c|c|}
\hline \multirow{4}{*}{\begin{tabular}{|l} 
\\
Rabbits
\end{tabular}} & \multicolumn{3}{|c|}{ CONTROLS } & \multicolumn{12}{|c|}{ ACETYLCHOLINE } \\
\hline & & & & \multicolumn{6}{|c|}{$0.5 \mathrm{mg}$} & \multicolumn{6}{|c|}{$0.1 \mathrm{mg}$} \\
\hline & & & & \multicolumn{3}{|c|}{$5 \mathrm{~min}$} & \multicolumn{3}{|c|}{$20 \mathrm{~min}$} & \multicolumn{3}{|c|}{$5 \mathrm{~min}$} & \multicolumn{3}{|c|}{$20 \mathrm{~min}$} \\
\hline & $\# 1$ & $\# 2$ & $\# 3$ & $\# 4$ & $\# 5$ & $\# 6$ & $\# 7$ & $\# 8$ & $\# 9$ & $\# 10$ & $\# 11$ & $\# 12$ & $\# 13$ & $\# 14$ & $\# 15$ \\
\hline Total number of $G C$ & 50 & 69 & 67 & 97 & 85 & 61 & 148 & 99 & 141 & 157 & 185 & 180 & 129 & 179 & 204 \\
\hline Non-stimulated GC & 48 & 66 & 66 & 5 & 5 & 6 & 104 & 76 & 121 & 42 & 45 & 42 & 12 & 17 & 16 \\
\hline Stimulated GC (total) & 2 & 3 & 1 & 92 & 80 & 55 & 44 & 23 & 20 & 115 & 140 & 138 & 117 & 162 & 188 \\
\hline Mucus-discharging $G C$ & 2 & 3 & 1 & 15 & 5 & 10 & 24 & 12 & 12 & 33 & 31 & 30 & 11 & 12 & 12 \\
\hline Degenerated GC & 0 & 0 & 0 & 77 & 75 & 45 & 20 & 11 & 8 & 82 & 109 & 108 & 106 & 150 & 176 \\
\hline GC arranged in groups & 3 & 2 & 6 & 4 & 6 & 7 & 64 & 55 & 81 & 11 & 10 & 6 & 8 & 11 & 10 \\
\hline
\end{tabular}

\section{Results}

In the pseudostratified columnar ciliated epithelium of the control rabbits' tracheae the goblet cells were found as isolated elements among the ciliated ones. Only $6 \pm 3 \%$ of them formed small groups (Graph 1). $97 \pm 1 \%$ of goblet cells were distended by large, light mucous granules (Graph 2). These cells reached the airways' lumen by means of small apical portions equipped by rather numerous tiny microvilli. They did not show any signs of secretion. The mucus discharging cells represented $3 \pm 1 \%$ (Graph 2 ). They evacuated mucus gradually from individual apical mucous granules. Exhausted secretory elements were not encountered in the epithelium.

Both $5 \mathrm{~min}$ and $20 \mathrm{~min}$ after i.v. administration of $0.1 \mathrm{mg}$ of acetylcholine and $5 \mathrm{~min}$ after administration of the larger dose of this drug the goblet cells were mostly scattered as isolated elements in the epithelium, only $5 \%$ to $7 \%$ of them being arranged in small groups. Due to the administration of $0.5 \mathrm{mg}$ of acetylcholine voluminous groups of secretory elements were noticed $20 \mathrm{~min}$ post exposure. In the formation of these intraepithelial mucous glands, $52 \pm 8 \%$ of the secretory elements participated (Graph 1 ).

Due to the acetylcholine administration, a marked increase in number of the stimulated goblet cells was recorded. They amounted to $22 \%-93 \%$ (Graph 3). $7 \%-12 \%$ of them were found in the phase of mucus evacuation (Plate I, Fig. 1). Secretion was discharged simultaneously from numerous apical mucous granules. The detachment of groups of mucous granules together with small amounts of the goblet cells' cytoplasm was also recorded (Fig. 2). In some cells massive fusion of the neighboring mucous granules was observed. The apical cell membranes of these cells, filled with voluminous masses of mucus, were frequently impaired (Fig. 3). 


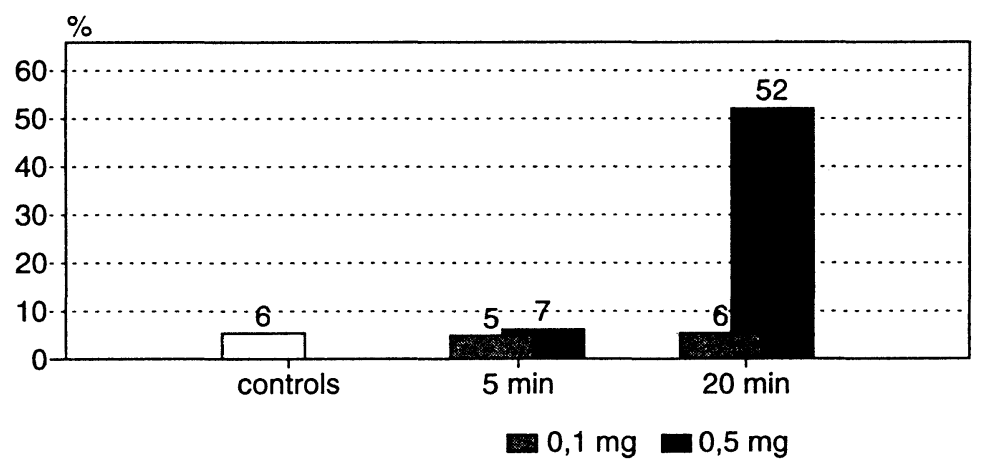

Graph 1: Goblet cells arranged in groups in the tracheal epithelium of rabbits 5 and 20 minutes after i.v. administration of $0.1 \mathrm{mg}$ and $0.5 \mathrm{mg}$ of acetylcholine

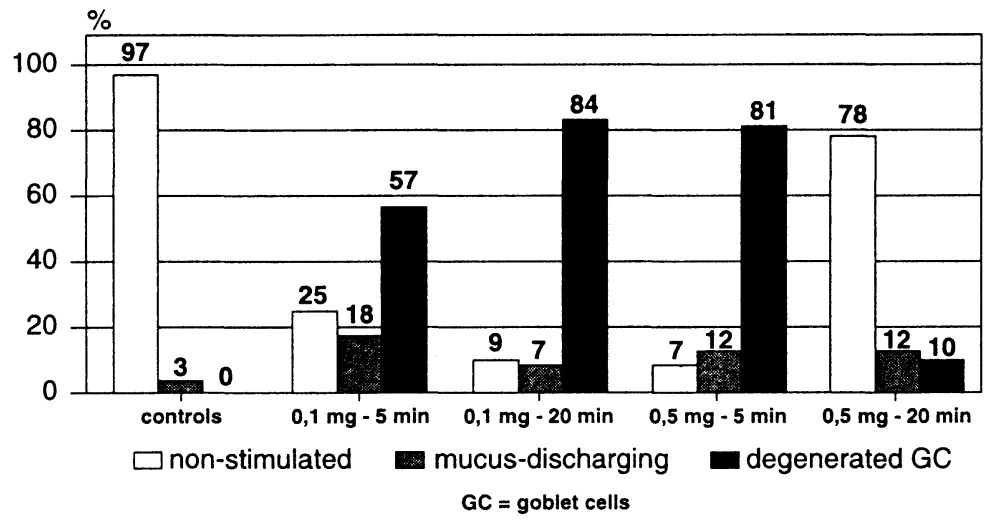

Graph 2: Goblet cells in the tracheal epithelium of rabbits 5 and 20 minutes after i.v. administration of $0.1 \mathrm{mg}$ and $0.5 \mathrm{mg}$ of acetylcholine

The completely exhausted goblet cells showing signs of degeneration represented $10 \%-84 \%$ of all secretory elements in the epithelium (Graph 4). They were often represented by narrow rims of highly condensed cytoplasm lining the cavities left after evacuation of the mucus content of the cell (Fig. 4). The degenerated goblet cells were gradually expelled from the epithelium. After loosening the contact with the basal lamina, their highly electron dense cytoplasm was encountered in the apical portions of the epithelium often bulging above the level of the surrounding cells (Fig. 5) and finally their remnants were observed in the area of the ciliary border (Plate II., Fig. 6). In the course of sloughing off the degenerated goblet cells new junctional complexes were created between the neighbouring cells. Thus the continuity of the epithelium was not impaired.

Twenty min after administration of $0.5 \mathrm{mg}$ of acetylcholine, an increase in number of the nonstimulated secretory elements was noticed. The proportion of these cells amounted to $78 \pm 8 \%$ (Graph 2). They were represented by mucus-filled goblet cells together with those filled with small mucous granules separated by wide cytoplasmic septa (Fig. 7), or elements containing in their undifferentiated cytoplasm a few cisternae of the granular endoplasmic reticulum, tiny Golgi complex and only isolated, often rather electron-dense secretory granules (Fig. 8). In the vicinity of the differentiating goblet cells also elements containing neither secretory granules, nor precursors of the basal bodies, within their highly undifferentiated cytoplasm were revealed. These cells often showed apical blebbing (Fig. 9). 


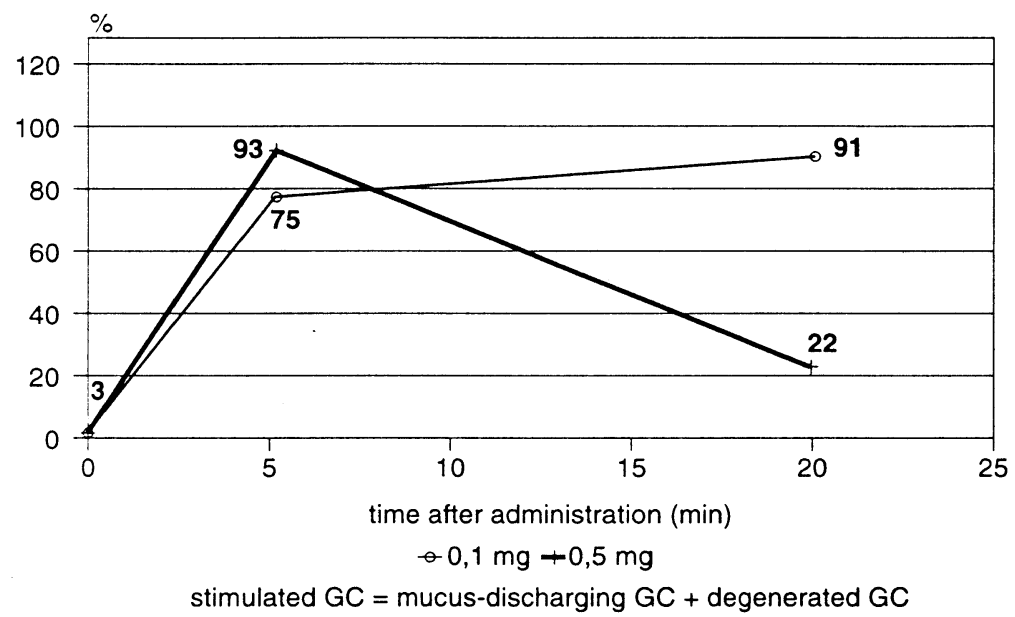

Graph 3: Stimulated goblet cells (GC) in the tracheal epithelium of rabbits 5 and 20 minutes after i. v. administration of $0,1 \mathrm{mg}$ and $0,5 \mathrm{mg}$ of acetylcholine

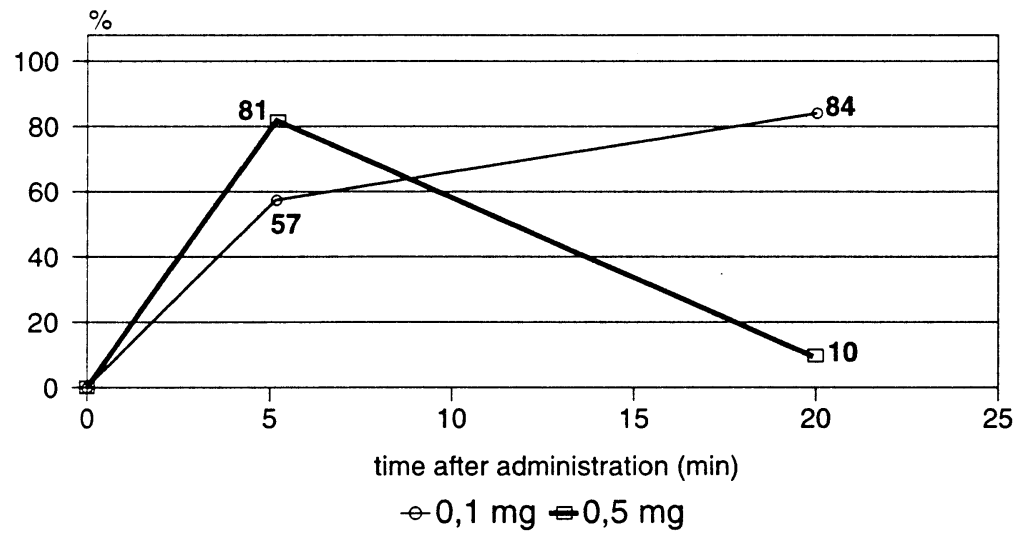

Graph 4: Degenerated goblet cells in the tracheal epithelium of rabbits 5 and 20 minutes after i.v. administration of $0.1 \mathrm{mg}$ and $0.5 \mathrm{mg}$ of acetylcholine

\section{Discussion}

The reaction of goblet cells in the airways' epithelium due to the administration of both doses of acetylcholine differed only from the quantitative point of view.

In agreement with other authors (Specian and Neutra 1980; Phillips and Wil s on 1993) we demonstrated that the goblet cells were overstimulated and the mechanism of their secretion was accelerated. In the controls the release of the small amount of mucus was classified as merocrine. As a sign of apocrine secretion, groups of mucous granules were detached from the goblet cells after acetylcholine administration. Also a rapid fusion followed by tandem fission of the neighboring mucous granule membranes was observed. According to Neutra, Schaffer, and Kurosumi, this process precedes the chain exocytosis. This most rapid method of mucus discharge was described in the goblet cells situated in the intestine mucous membrane after acetylcholine administration (Ne u tra and Sch a ef fer 1977; K u rosu mi et al. 1981).

Due to acetylcholine administration the secretory elements in the epithelium lining the 
rabbits' tracheae were not only overstimulated but also damaged. After rapid evacuation of their secretion, they mostly did not take part in the further secretory cycles but they degenerated and were gradually expelled from the epithelium.

In our previous studies we demonstrated that the degeneration of more than half of the goblet cells in the epithelium was always followed by a massive differentiation of new secretory elements (Kon rádová 1991, 1995; Kon rád ová et al. 1990). As the differentiating secretory cells are still able to divide (B ecci et al. 1978), a hyperplasia of goblet cells and the appearance of voluminous intraepithelial mucous glands were usually later encountered. 20 min after administration of $0.5 \mathrm{mg}$ of acetylcholine, a significant change in the distribution of the secretory elements was recorded together with the appearance of numerous undifferentiated elements and different stages of the goblet cells' development. "Small mucous granule cells", described by some authors as differentiating secretory elements (Becci et al. 1978: Wilson et al. 1984; Tyler and Plopper 1985), were frequently observed.

Due to the administration of both doses of acetylcholine more than $90 \%$ of goblet cells were stimulated to discharge their mucus (Graph 3). After administration $0.1 \mathrm{mg}$ of acetylcholine the reaction was more prolongated. A marked increase in the number of nonstimulated goblet cells, encountered $20 \mathrm{~min}$ after administration of $0.5 \mathrm{mg}$ of acetylcholine, reflected the accelerated differentiation of new secretory cells. The proportion of the mucus-discharging elements increased only in the first phases post exposure. The peak values of the degenerated goblet cells did not differ significantly after administration of both doses of acetylcholine (Graph 4). Due to the smaller dose, the high level of the goblet cells' injury was reached later.

Based on our previous studies, a classification of the degree of damage to the goblet cells was proposed (K o n rád o vá 1991). We took into consideration the proportion of the stimulated cells and also the degree of the acceleration of the mechanism of their secretion. The evaluation of secretion was based on the ratio of the less damaged mucus discharging and exhausted degenerated cells. According to our criteria we classified the injury to the goblet cells as mild (I) to severe (III) (Table 2).

After administration of both $0.1 \mathrm{mg}$ and $0.5 \mathrm{mg}$ of acetylcholine, the degree of injury to the goblet cells was classified as severe, and $0.1 \mathrm{mg}$ of this drug caused higher increase of the goblet cells' injury. Due to the administration of $0.5 \mathrm{mg}$ of acetylcholine, the course of the whole reaction was faster and 20 min post exposure first signs of goblet cells' repair were observed (Table 2).

Table 2

Classification of the degree of injury to the goblet cells in rabbits 5 and 20 minutes after administration of $0.1 \mathrm{mg}$ and $0.5 \mathrm{mg}$ of acetylcholine

\begin{tabular}{|c|c|c|c|}
\hline $\mathrm{GC}=$ goblet cells & $\underset{I}{\operatorname{mild}}$ & $\begin{array}{l}\text { Degree of inje } \\
\text { moderate } \\
\text { II }\end{array}$ & $\begin{array}{c}\text { severe } \\
\text { III }\end{array}$ \\
\hline Stimulated GC & $<50 \%$ & $50-90 \%$ & $>90 \%$ \\
\hline$\frac{\text { Discharging GC }}{\text { Degenerated GC }}$ & $>1$ & $0.1-1$ & $<0.1$ \\
\hline
\end{tabular}

\begin{tabular}{|c|c|c|c|}
\hline \multicolumn{4}{|c|}{ Acetylcholine } \\
\multicolumn{3}{|c|}{$0.1 \mathrm{mg}$} & \multicolumn{2}{c|}{$0.5 \mathrm{mg}$} \\
\hline $\mathrm{min}$ & $20 \mathrm{~min}$ & $5 \mathrm{~min}$ & $20 \mathrm{~min}$ \\
\hline $75 \%$ & $91 \%$ & $93 \%$ & $2 \%$ \\
II & III & III & I \\
\hline 0.32 & 0.08 & 0.15 & 1.20 \\
II & III & II-III & I \\
\hline
\end{tabular}

\section{Reakce pohárkových buněk na cholinergní stimulaci}

Sledovali jsme reakci pohárkových buněk tracheálního epitelu králíků, vyvolanou intravenózním podáním $0.1 \mathrm{mg}$ a $0.5 \mathrm{mg}$ acetylcholinu. Pohárkové buňky tak byly nadměrně stimulovány, mechanismus jejich vyprazdňování byl urychlen a po urychleném výdeji sekretu sekreční elementy většinou degenerovaly. Po podání obou dávek acetylcholinu bylo k výdeji 
hlenu stimulováno více než $90 \%$ pohárkových buněk. Po podání $0.1 \mathrm{mg}$ acetylcholinu byla tato reakce protrahována, ale vrcholné hodnoty počtu degenerovaných pohárkových buněk se po podání obou dávek látky významně nelišily. 20 minut po podání $0.5 \mathrm{mg}$ acetylcholinu byly zjištěny známky masivní diferenciace nových sekrečních elementů.

\section{Acknowledgements}

This work was supported by Charles University Internal Grant $\mathrm{N}_{234}$.

\section{References}

AFZELIUS, B. A. 1976:A human syndrome caused by immotile cilia. Science, 193:317-319

BECCI, P., McDOWELL, E. M., TRUMP, B. F. 1978:The respiratory epithelium. J.Natl.Cancer Inst. 61:551-561 BRYAN, J. H. D. 1983:Abnormal cilia in a male-sterile mutant mouse. Virchows Arch.(Pathol.Anat.) 400:77-86 EDWARDS, D. F., KENNEDY, J. R., PATTON, C. S., TOAL, R. L., DANIEL, G. B., LOTHROP, C. D. 1989:Familial immotile-cilia syndrome in English springer spaniel dogs. Am. J. Med. Genet. 33:290-298

FUNG, D. C. K., BEACOCK, D. J., RICHARDSON, P. S. 1992:Vagal control of mucus glycoconjugate secretion into the feline trachea. J. Physiol. 453:435-447

KONRÁDOVÁ, V. 1991:Quantitative evaluation of the degree of damage to tracheal epithelium. Funct. Dev. Morphol. 1:47-50

KONRÁDOVÁ, V. 1995:Epitel dýchacích cest a jeho reakce na různé Skodliviny. Ćasopis lékarŭ českých 134:440444

KONRÁDOVÁ, V., ŚRAJER, J. 1987:Quantitative evaluation of the ciliary border of the epithelium of the rabbit trachea and the human primary bronchus. Folia Morphol. 35:67-74

KONRÁDOVÁ, V., KANTA, J., ŚULOVÁ J. 1990:Effect of the bronchoalveolar lavage on the ultrastructure of the tracheal epithelium in rabbits. Respiration 57:14-20

KUROSUMI, K., SHIBUICHI, I., TOSAKA, K. 1981:Ultrastructural studies on the secretory mechanism of goblet cells in rat jejunal epithelium. Arch. Histol. Jap. 44:263-284

NEUTRA, M. R., SCHAEFFER, S. F. 1977:Membrane interactions between adjacent mucous secretion granules. J. Cell Biol. 74:983-991

PHILLIPS, T. E., WILSON, J. 1993:Morphometric analysis of mucous granule depletion and replenishment in rat colon. Digest. Dis. Sci. 38:2299-2304

RAMNARINE, S. I., ROGERS, D. F. 1994:Non-adrenergic, non-cholinergic neural control of mucus secretion in airways. Pulmonary Pharmacology 7:19-33

ROPERTO, F., GALATI, P., ROSSACCO, P. 1993:Immotile cilia syndrome in pigs. A model for human disease. Am. J. Pathol. 143:643-647

ROUMAGNAC, I., LABOISSE, C. 1987:A mucus-secreting human colonic epithelial cell line responsive to cholinergic stimulation. Biology of the Cell 61:65-68

SPECIAN, R. D., NEUTRA, M. R. 1980:Mechanism of rapid mucus secretion in goblet cells stimulated by acetylcholine. J. Cell Biol. 85:626-640

TOKUYAMA, K., KUO, H., ROHDE, J. A. L., BARNES, D. J., ROGERS, D. F. 1990: Neural control of goblet cell secretion in guinea pig airways. Am. J. Physiol. 259:L108-L115

TYLER, N. K., PLOPPER, C. G. 1985:Morphology of distal conducting airways in rhesus monkey lungs. Anat. Rec. 211:295-303

UHLIK, J., KONRÁDOVÁ, V., SRAJER, J., ZAJICOVA, A. 1995:An abnormally high occurrence of malformed kinocilia in the tracheal epithelium of a clinically healthy rabbit. Vet. Med. 40:243-248

WILSMAN, N. J., MORRISON, W. B., FARNUM, C. E., FOX, L.E. 1987: Microtubular protofilaments and subunits of the outer dynein arm in cilia from dogs with primary ciliary dyskinesia. Am. Rev. Respir. Dis. 135:137-143

WILSON, D. W., PLOPPER, C. G., HYDE, D. M. 1984:The tracheobronchial epithelium of the bonnet monkey. Am. J. Anat. 171:25-40

Address for correspondence:

Doc.MUDr.V.Konrádová, DrSc.

Institute of Histology and Embryology

$2^{\text {nd }}$ Medical Faculty, Charles University
V úvalu 84

CZ-150 18, Praha 5

Czech Republic 
Plate I.

Konrádová V. et al.: Reaction... pp. 175-180
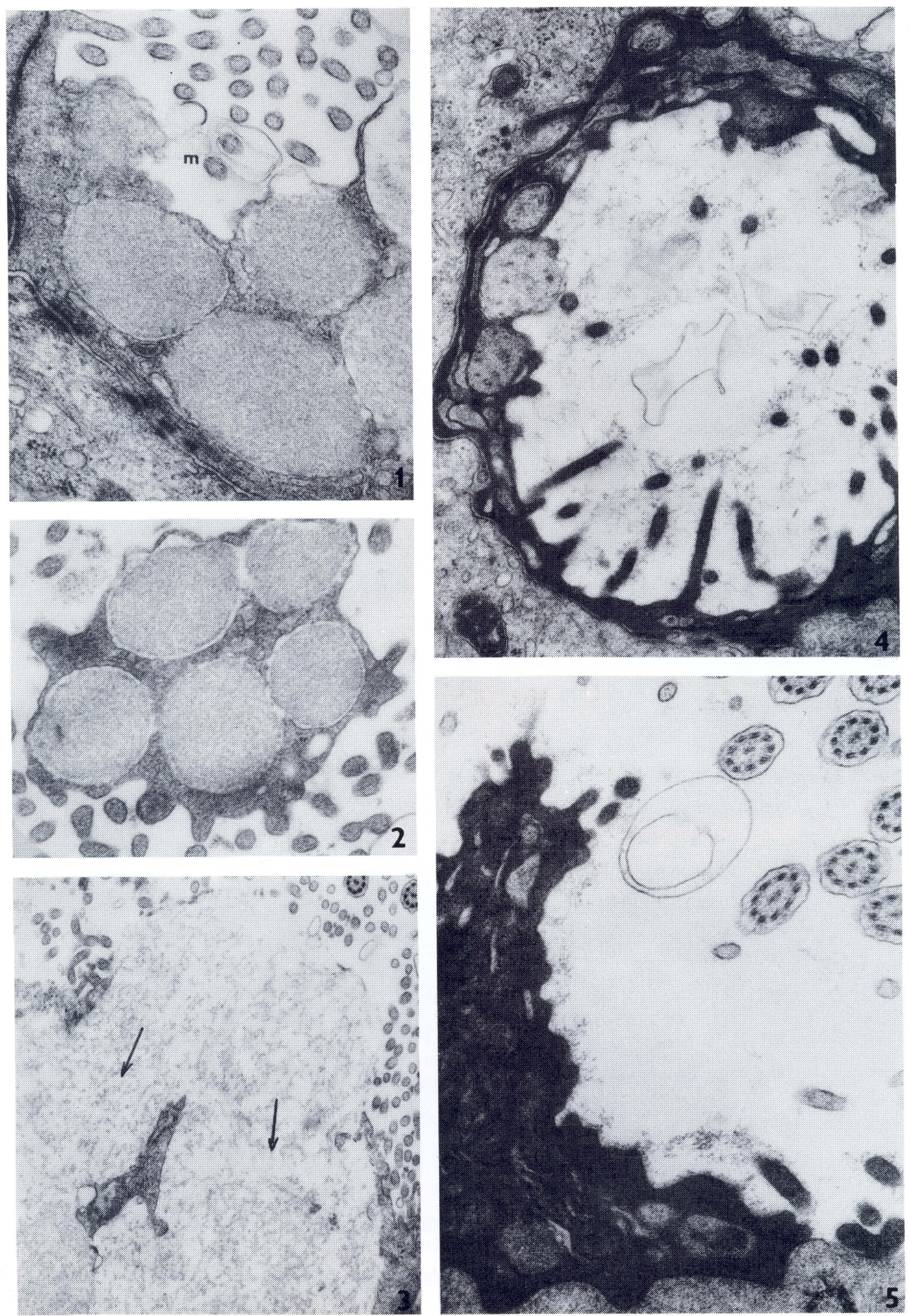


\section{Description of electronograms}

Plate I.

Fig.1: Apical portion of stimulated goblet cells with remnants of membranes of evacuated mucous granules $(\mathrm{m})$. TEM, 50,000x, $5 \mathrm{~min}$ after administration of $0.1 \mathrm{mg}$ of acetylcholine

Fig.2: Group of mucous granules detached from a goblet cell. TEM, 50,000x, 20 min after administration of $0.1 \mathrm{mg}$ of acetylcholine

Fig.3: Apical portion of goblet cell filled with voluminous mucus mass. The apical cell membrane is impaired (arrow). TEM, 25,000x, $20 \mathrm{~min}$ after administration of $0.1 \mathrm{mg}$ of acetylcholine

Fig.4: Rim of degenerated highly electron-dense cytoplasm of the exhausted goblet cell lining the cavity left after mucous granules' evacuation. TEM, 37,500x, $5 \mathrm{~min}$ after administration of $0.5 \mathrm{mg}$ of acetylcholine

Fig.5: Portion of the degenerated goblet cell's cytoplasm bulging in the area of the ciliary border. TEM, 50,000x, $5 \mathrm{~min}$ after administration of $0.5 \mathrm{mg}$ of acetylcholine 
Plate II.
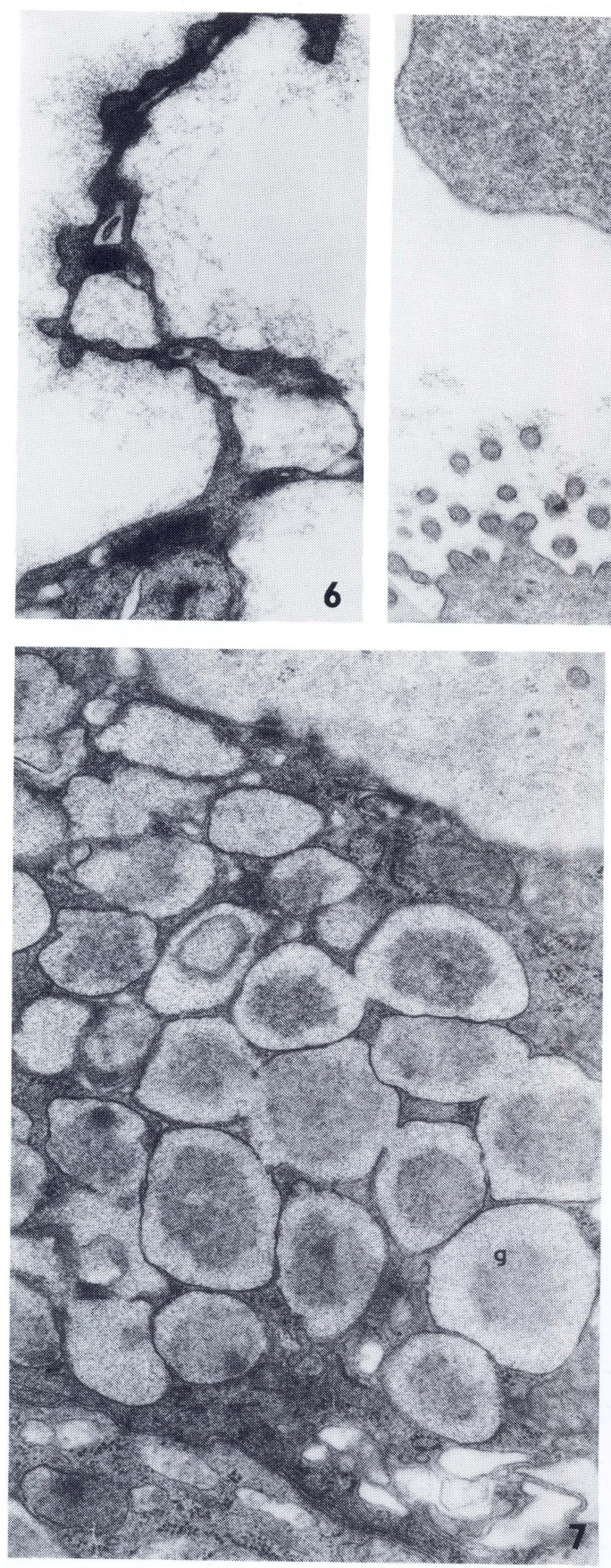
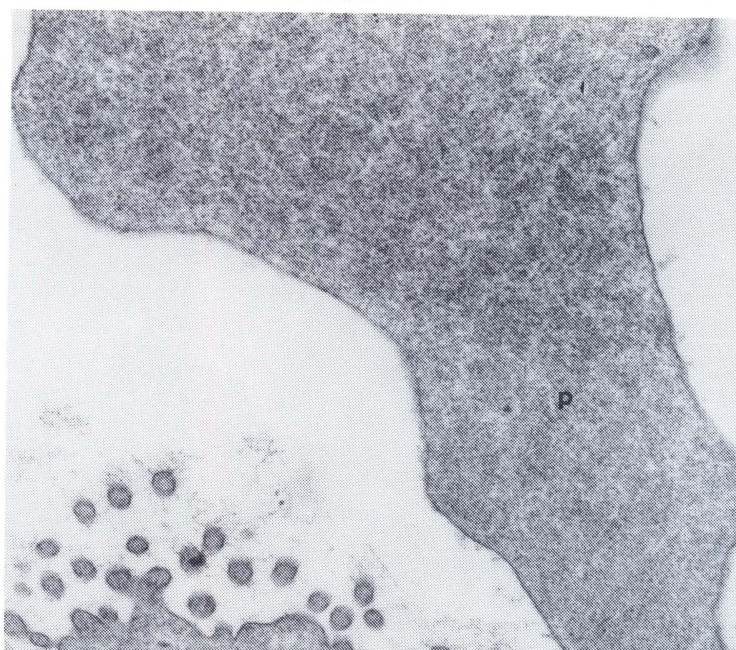

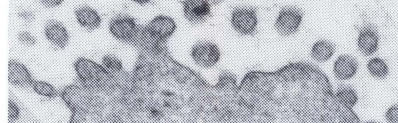
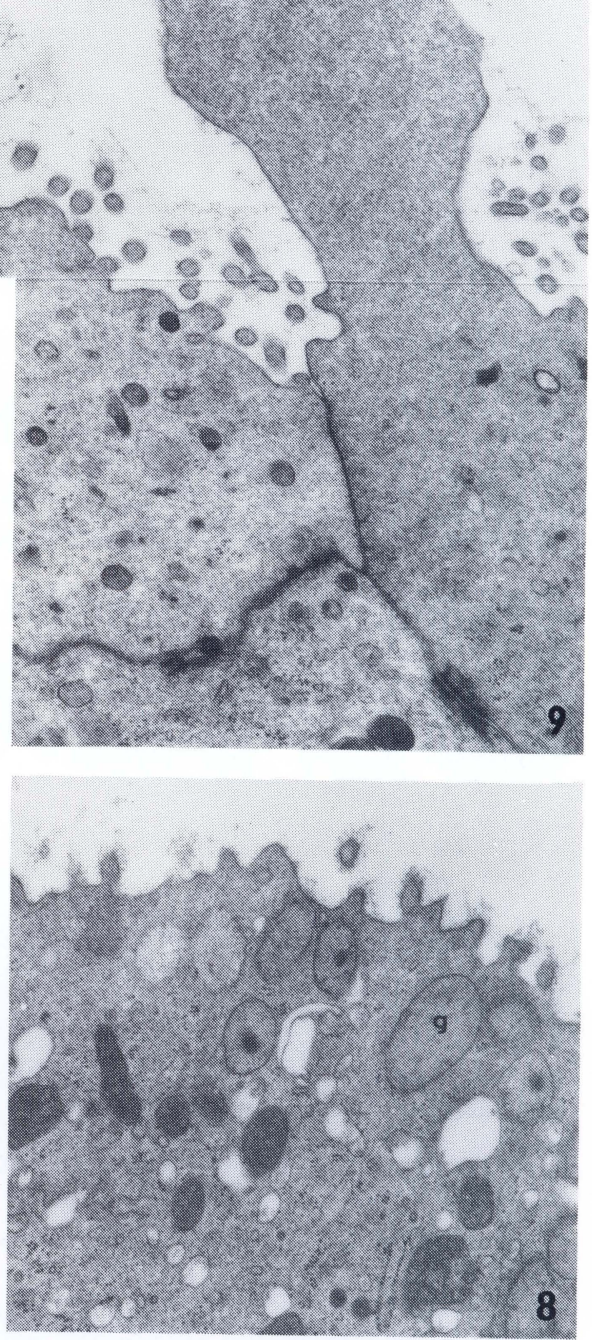
Plate II.

Fig.6: Remnant of highly electron dense cytoplasm of sloughed off exhausted goblet cell. TEM, 50,000x, $5 \mathrm{~min}$ after administration of $0.5 \mathrm{mg}$ of acetylcholine

Fig.7: Goblet cell filled with small mucous granules (g). TEM, 37,500x, 20 min after administration of $0.5 \mathrm{mg}$ of acetylcholine

Fig.8: Apical portion of the differentiating secretory cell with isolated small moderately dense secretory granules (g). TEM, 25,000x, $20 \mathrm{~min}$ after administration of $0.5 \mathrm{mg}$ of acetylcholine

Fig.9: Voluminous cytoplasmic protrusion (p) on the apical portion of the undifferentiated cell. TEM, 25,000x, $20 \mathrm{~min}$ after administration of $0.5 \mathrm{mg}$ of acetylcholine 